\title{
Detection, Identification and Quantification of Fusarium graminearum and Fusarium culmorum in Wheat Kernels by PCR Techniques
}

\author{
Rabab Sanoubar ${ }^{1 *}$, Astrid Bauer ${ }^{2}$ and Luitgardis Seigner ${ }^{2}$
}

${ }^{1}$ Department of Horticulture, Agriculture Faculty, Damascus University, Syria

${ }^{2}$ linstitute of Plant protection (Bayerische Landesanstalt für Landwirtschaft Institut für Pflanzenschutz, LfL), Freising, Germany

\begin{abstract}
This study was carried out on 172 samples of winter wheat. The samples consisted of various cultivars that had been randomly collected from farmers' fields in different areas of Bavaria, South Germany. The objectives of this study were detecting the presence of Tri-5 gene producing fungus that generates trichothecene mycotoxins, especially Deoxynivalenol (DON), by using conventional qualitative PCR; determining the correlation between the presence of Tri-5 gene and DON content; evaluating the Fusarium graminearum and Fusarium culmorum infection by Real-Time PCR and estimating the correlation between DON content and the severity of $F$. graminearum and F. culmorum contamination. This study showed that $86 \%$ of all infected samples had a Tri-5 gene and amplified a single 544bp fragment associated with a detectable amount of DON (ranged from 10 to $2990 \mu \mathrm{g} \mathrm{kg}^{-1}$ ). This study demonstrated that $F$. graminearum is the predominant species associated with Fusarium head blight (FHB) and was considered as the predominant trichothecene producer that associated with FHB since there was a highly significant correlation $\left(R^{2}=0.7\right)$ between DON and $F$. graminearum DNA content, compared to a weak correlation $\left(R^{2}=0.03\right)$ between DON and DNA content of $F$. culmorum infected wheat kernels.
\end{abstract}

Keywords: Wheat; Fusarium head blight; Tri-5 gene; Trichothecene DON; Conventional; Real-time PCR

\section{Introduction}

Fusarium head blight (FHB) of small grains was first described over a century ago and was considered as a major threat to wheat and barley during the early years of last century [1]. Head blight or scab of wheat caused epidemics in many wheat area worldwide $[2,3]$. The International Maize and Wheat Improvement Centre (CIMMYT) have considered FHB as a major factor limiting wheat production in many parts of the world [2]. FHB is also known as "tombstone" kernels of wheat because of the chalky and lifeless appearance of the infected kernels [4]. It has the capacity to destroy a potentially high-yielding crop within few weeks [5]. FHB is a significant disease of small-grain cereals throughout Europe [3], United States [6], Canada [7], South America [8], Asia [9] and Australia [10]. FHB was identified more than 120 years ago, in 1884, in England. The United States Department of Agriculture ranked FHB as the worst plant disease to appear since the 1950 's [11]. It has increased worldwide [12] and it was considered as a major threat to wheat and barley during the early years of the twentieth century $[13,14]$.

FHB is caused by a number of different fungal species of the genus Fusarium (Fusarium spp). However, F. avenaceum, F. culmorum, F. graminearum (teleomorph, Gibberella zeae), F. poae, and Microdochium nivale (teleomorph, Monographella nivalis) are the species which are most commonly associated with the FHB disease [15].

The threat posed by Fusarium spp. is multifaceted. It causes yield and quality losses due to sterility of the florets and formation of discolouration, which reduces kernel size and losses light weight kernels [9]. In addition, grain quality factors such as protein content and germination can be severely affected by the pathogen [16]. Several Fusarium species which cause FHB are able to produce trichothecene mycotoxin. F. culmorum, F. graminearum, and F. poae produce type $B$ trichothecenes such as nivalenol (NIV), deoxnivalenol (DON), and fusaenon-X [17], while other species are not [18]. DON is the predominant Trichothecenes found in Europe and North America
[19]. Trichothecene produced by this fungus pose a serious hazard to human and animal health [10] because these toxic materials are potent inhibitors of eukaryotic protein biosynthesis [20,21]. Acute adverse effects of the toxin in animals causes weight loss and feeding refusal in non-ruminant livestock, high rates of abortion, diarrhoea, emesis, alimentary haemorrhagy and contact dermatitis [22]. Human ingestion of grain contaminated with $F$. graminearum has been associated with alimentary toxicity as well as illness characterized by nausea, vomiting, anorexia, and convulsions [23]. Trichothecenes are also powerful modulators of human immune function and may promote neoplasms, cause autoimmune disease, or have long-term effects on resistance to infectious disease by altering immune response [24,25].

Several genes of Fusarium are involved in the biosynthesis of trichothecene and most of them are localized in a Tri gene cluster. The Tri-5 gene encodes the enzyme trichodiene synthase [26], which catalyzes the first step in the trichothecene biosynthetic pathway in trichothecene-producing strains of Fusarium species. The development of Tri-5 gene specific primers has allowed trichothecene-producing Fusarium spp. to be distinguished from nonproducing species using PCR-based assays [27]. The nucleotides sequence of the Tri-5 gene has been characterized in several Fusarium species [28,29].

The main objectives of this study were detecting the presence of Tri-5 gene producing fungus, which encodes the key enzyme in trichothecene production, especially DON, by using conventional

*Corresponding author: Rabab Sanoubar, Department of Horticulture, Agriculture Faculty, Damascus University, Syria, E-mail: rabab.sanoubar@unibo.it

Received June 14, 2015; Accepted July 04, 2015; Published July 08, 2015

Citation: Sanoubar R, Bauer A, Seigner L (2015) Detection, Identification and Quantification of Fusarium graminearum and Fusarium culmorum in Wheat Kernels by PCR Techniques. J Plant Pathol Microb 6: 287. doi:10.4172/21577471.1000287

Copyright: (c 2015 Sanoubar R, et al. This is an open-access article distributed under the terms of the Creative Commons Attribution License, which permits unrestricted use, distribution, and reproduction in any medium, provided the original author and source are credited. 
PCR; determining the correlation between the presence of Tri-5 gene and the DON content, which was analysed by the chemist Dr. Puttner. $J$. Lepschy; evaluating the amount of F. graminearum and F. culmorum infection through Real-Time PCR assay; investigating the relationship between DON content and the degree of $F$. graminearum and $F$. culmorum contamination and determining the aggressiveness of FHB towards plant host.

\section{Materials and Methods}

\section{Fungal reference material}

50 ng of extracted DNA from F. graminearum isolates were applied in tenfold serial dilutions $\left(10^{-1}\right.$ to $\left.10^{-4}\right)$ as a quantitative standard in Real-Time PCR (RT-PCR) using a F. graminearum specific Taqman hybridization probe for beta-tubulin gene. In parallel, $50 \mathrm{ng}$ of DNA of $F$. culmorum strains were used in tenfold serial dilution also as a quantitative standard for RT-PCR using SYBR Green 1 .

\section{Plant material}

At harvest time, 172 winter wheat ears samples of various cultivars have been randomly collected from farmers' fields in different areas of Bavaria, South Germany. Directly after harvest, samples were sent to the Institute of Plant Protection, $\mathrm{LfL}$ and preserved at $-20^{\circ} \mathrm{C}$.

\section{DNA extraction}

DNA of infected wheat kernels was extracted by homogenising $10 \mathrm{mg}$ of dried kernels in a mixer with the presence of $1 \mathrm{ml}$ DNA extraction buffer (2\% CTAB, $1.4 \mathrm{M} \mathrm{NaCl}, 100 \mathrm{mM}$ Tris, $20 \mathrm{mM} \mathrm{Na}$ EDTA, and 1\% PVP-40). The mixture was vortexed and the flow was transferred to microcentrifuge tubes. $1 \mathrm{ml}$ chloroform/isoamylalkohol (24:1) was added, well mixed and spined at $5000 \times \mathrm{g}$ for 10 minute at $20^{\circ} \mathrm{C}$. The aqueous phase containing DNA molecules was transferred into $2 \mathrm{ml}$ fresh tubes where $100 \mu \mathrm{l} \mathrm{Na}$-acetat (3M, pH 5.2) and $1 \mathrm{ml}$ isopropanol $\left(-20^{\circ} \mathrm{C}\right)$ were added and mixed by inverting the tubes many times. Tubes were placed in a freezer $\left(-20^{\circ} \mathrm{C}\right)$ for at least 1 hour. For each sample, the lysate mixture was transferred to SV Minicolumn placed in $1.5 \mathrm{ml}$ tubes and spined at $16.000 \times \mathrm{g}$ for 1 minute at $4^{\circ} \mathrm{C}$. The supernatant was discarded, and the SV Minicolumns were washed with ethanol many times as described by (30). Finally, $50 \mu$ of distilled sterile water was added directly into SV Minicolumn which was placed in $1.5 \mathrm{ml}$ microcentrifuge tube and incubated at room temperature for 5 minutes then spined at $16.000 \times \mathrm{g}$ for 2 minutes at $4^{\circ} \mathrm{C}$ to collect the eluted DNA [30].

\section{PCR assay}

Two Tri-5 specific primers have been used to detect the presence of Tri-5 gene in F. spp. infected wheat kernels. 172 wheat samples were tested with a sample of $F$. graminearum used as a positive control. The sequences of these primers are: forward primer Tri-5 F: (5'-AGCGACTACAGGCTTCCCTC-3') and reverse primer Tri-5 R: (5'-AAACCATCCAGTTCTCCATCTG-3'). These primers were derived from the conserved region of Tri-5 gene in Fusarium spp. Tri-5 primers ( $\operatorname{Tr} 5 \mathrm{~F}$ and $\operatorname{Tr} 5 \mathrm{R})$ amplified a single 544bp fragment in both DNA extracted of F. graminearum and F. culmorum and DNA of infected wheat grains. The total volume of reaction master mix was 22.7 $\mu$ l. The PCR amplification was performed using $\left(2.7 \mu \mathrm{lof} 25 \mu \mathrm{g} \mathrm{ml}^{-1}\right)$ of both fungal $F$. graminearum DNA and DNA from $10 \mathrm{mg}$ dry weight of wheat material, $0.5 \mu \mathrm{M}$ of each of the Tri-5-specific primers, $0.8 \mathrm{mM}$ concentration of nucleotides dNTPs, 0.5 unit of Taq polymerase and $2.27 \mu \mathrm{l}$ of PCR buffer with $1.5 \mathrm{mM} \mathrm{MgCl}_{2}$. The PCR negative control was a reaction master mix with $2.7 \mu$ of distilled water instead of DNA template. Cycler programme was set as the following: one cycle at $95^{\circ} \mathrm{C}$ for $75 \mathrm{~s}$ then 32 cycles of $94^{\circ} \mathrm{C}$ for $20 \mathrm{~s}, 62^{\circ} \mathrm{C}$ for $17 \mathrm{~s}, 72^{\circ} \mathrm{C}$ for $45 \mathrm{~s}$, and a final cycle at $72^{\circ} \mathrm{C}$ for $4 \mathrm{~min}$ and $15 \mathrm{~s}$. DNA banding were revealed by electrophoresis at $90 \mathrm{v}$ on $2 \%$ agarose gels in $1 \mathrm{x}$ Tris-acetate EDTA buffer (TAE) (where 50X TAE contained: 2M Tris, 1M Acetic Acid, and $0.1 \mathrm{M} \mathrm{Na}$-EDTA $\times 2 \mathrm{H}_{2} \mathrm{O}$ at $\mathrm{PH}$ 8.0) using ethidium bromide staining ( $30 \mu \mathrm{g}$ of a ethidium bromide for $100 \mathrm{ml}$ of $1 \mathrm{X}$ TAE buffer) and photographed under UV light using a camera and a photo print image visualizer.

\section{Quantification of $F$. species by Real-Time PCR}

Quantification of $F$. graminearum by RT-PCR using a TaqMan probe assay: Two primers, derived from the consensus beta-tubulin sequence which is associated with head blight in wheat, were used for F. graminearum quantification. The forward primer FGtubf: (5'-GTCTCGACAGCAATGGTGTT-3') and reverse primer FGtubr: (5'-GCTTGTGTTTTTCGTGGCAGT-3') specifically amplified a $111 \mathrm{bp}$ fragment of the beta-tubulin gene of $F$. graminearum which was quantified by the TaqMan probe FGtubTM (FAM5'ACAACGGAACGGCACCTCTGAGCTCCAGC3'-TAMRA). PCR was monitored on a Real-Time 7000 Sequence Detection System. PCR Master Mix contained: Hot Start Taq DNA polymerase and PCR buffer specifically adopted for quantitative PCR analysis using species-specific probes. The total volume of master mix reaction $(23 \mu \mathrm{l})$ contained: optimal primer concentrations $0.3 \mu \mathrm{M}$ of FGtubf and FGtubr primers, $1 \mathrm{x}$ PCR buffer, $50 \mathrm{ng}$ of template wheat DNA samples, and $0.2 \mu \mathrm{M}$ of TaqMan probe, and $50 \mathrm{ng}$ of $F$. graminearum dilution template DNA as a standard curve. There were four series of diluted standard curves, with 1:10 fold of dilution factor of F. graminearum DNA. The number of cycles in the PCR was set at 40 , as the $40^{\text {th }}$ cycle represented the extrapolated threshold cycle for a reaction with a theoretical single copy of the template DNA. PCR program was as the following: $95^{\circ} \mathrm{C}$ for $15 \mathrm{~min}, 40 \mathrm{cycles}$ of $95^{\circ} \mathrm{C}$ for $15 \mathrm{~s}$ and $67^{\circ} \mathrm{C}$ for $1 \mathrm{~min}$. All reactions were performed in triplicates. PCR efficiency was calculated from threshold cycles of the standard dilution curve.

Quantitation of $F$. culmorum by Real-Time PCR using DNA binding dye assay: Two specific primers were used for the detection of $F$. culmorumbyamplifying $140 \mathrm{bp}$ fragment of F.culmorum. Forward primer sequence Fc03: (5'-TTCTTGCTAGGGTTGAGGATG-3') and reverse primer sequence Fc02: (5'-GACCTTGACTTTGAGCTTCTTG-3') were specifically amplified a $140 \mathrm{bp}$ fragment of $F$. culmorum genome that was quantified by the DNA binding dye, SYBR' Green 1 . The SYBR Green 1 assay is similar to that of TaqMan assay except the presence of an intercalating agent such as fluorescent dye SYBR Green 1 instead of fluorescent probes TaqMan.

\section{Results}

\section{Detection of Tri-5 gene}

The Tri-5 specific PCR assay could provide a screening tool for detection of trichothecene-producing Fusarium species in plant tissues. In this study, 172 DNA samples of infected wheat kernels were analyzed using Tri-5 gene primers in a PCR reaction to detect trichothecene producing Fusarium species. The separation of PCR products on agarose gels showed that $86 \%$ of DNA samples possessed a unique fragment of $544 \mathrm{bp}$ representing part of the Tri-5 gene while $14 \%$ of samples didn't show any amplification product (Figure 1).

The same wheat samples were used to estimate the content of DON 
Citation: Sanoubar R, Bauer A, Seigner L (2015) Detection, Identification and Quantification of Fusarium graminearum and Fusarium culmorum in Wheat Kernels by PCR Techniques. J Plant Pathol Microb 6: 287. doi:10.4172/2157-7471.1000287

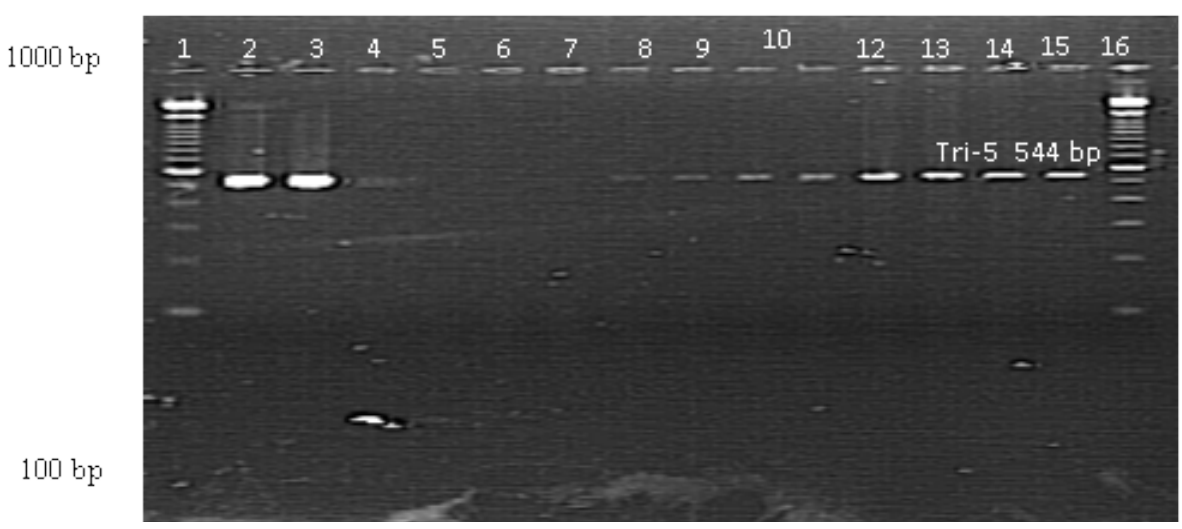

Figure 1: Analysis of DNA samples with specific primers (Tri-5 gene) on $2 \%$ agarose gel.

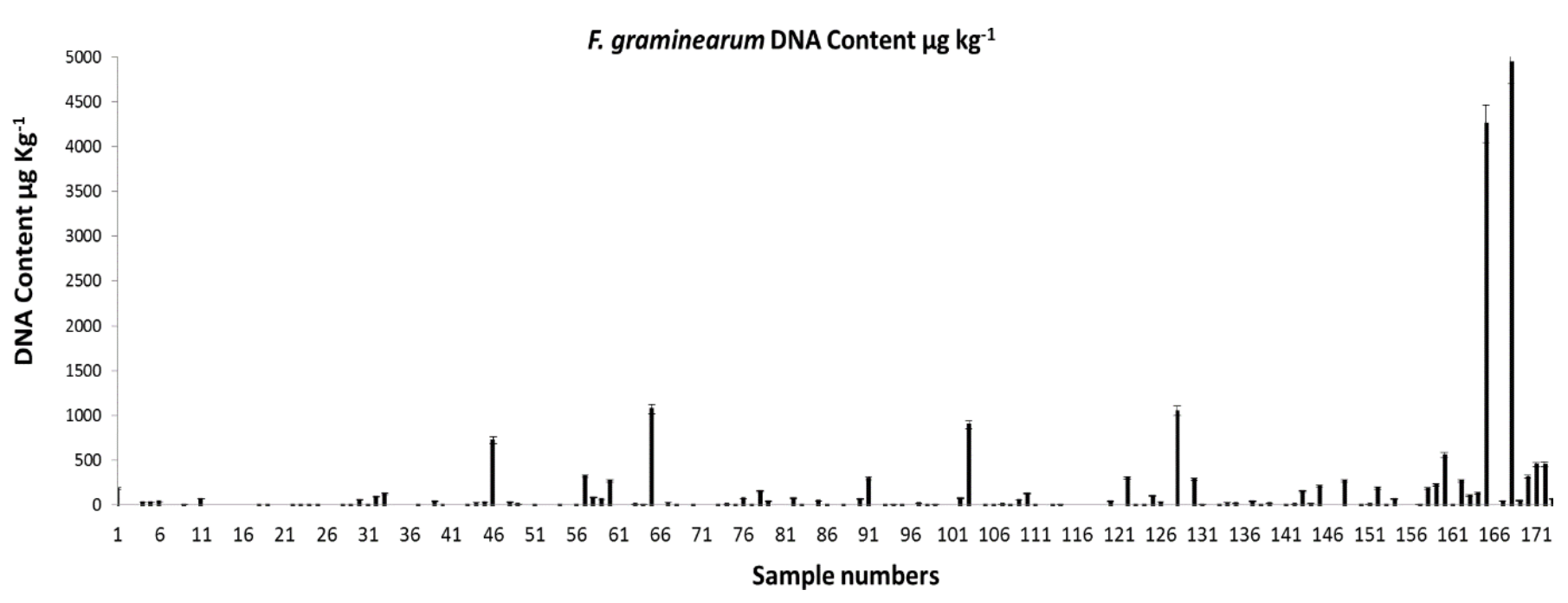

Figure 2: Infestation by F. graminearum in wheat samples harvest by Real-Time TaqMan probe. Samples were tested in triplicates.

in their tissues determined by HPLC (results provided by the chemist Dr. puttner J. Lepschy, LfL). The quantity of DON varied between the samples leading to regroup the samples into 3 categories according to their DON content.

The comparison between the amplification products produced with Tri-5 gene primers and the DON contents demonstrated that the samples free of Tri-5 gene products ( $14 \%$ of all samples) showed either absence of DON in their tissues (in 7\% of all samples) or detected an amount of DON ranged from 11-226 $\mu \mathrm{g} \mathrm{kg}^{-1}$ (in $7 \%$ of all samples).

For all samples possessing 544bp DNA fragments $(86 \%$ of all samples), an amount of DON was detected in their tissues. Approximately $76 \%$ of them (59\% of all samples) were considered DON high-producing strains (101-2990 $\mathrm{g} \mathrm{kg}^{-1}$ ) and possessing an intensive DNA band on agarose gels, while $14 \%$ of them $(27 \%$ of all samples) were considered DON low-producing strains (10-99 $\left.\mu \mathrm{g} \mathrm{kg}^{-1}\right)$ and showing a faint DNA band at 544bp.

Line 1, 16 standards 100 bp. Lines 2, 3 F. graminearum DNA used as positive control. Lines (4-15) some tested wheat samples: lines (5-7) free of DNA band, Lines $(4,8-11)$ faint bands, and lines (12-15) bright bands at $544 \mathrm{bp}$.

\section{Quantification of F. graminearum and F. culmorum using Real-Time PCR}

The specific primers and TaqMan hybridization probe targeting the beta-tubulin gene amplifies DNAs from F. graminearum infected wheat. Based on determination of threshold cycle (Ct-values) in individual samples and known DNA standards during Real-Time PCR, amounts of target DNA present in the samples were calculated. The amplification of standard dilution curves of $F$. graminearum in RealTime PCR gave linear and reliable results $\left(\mathrm{R}^{2}\right.$ values were between 0.997 and 0.989$)$. The concentration of $F$. graminearum DNA ranged from 0.04 to $4945 \mu \mathrm{g} \mathrm{kg}^{-1}$ (mean of triplicate samples ranged from 9.19E-07 to $1.29 \mathrm{E}-01 \mu \mathrm{g} \mathrm{ml}^{-1}$ ) of dry weight wheat kernels (Figure 2), while, F. culmorum DNA content was limited and ranged between 0.04 and $39.22 \mu \mathrm{g} \mathrm{kg}^{-1}$ (mean of triplicate samples ranged from $8.00 \mathrm{E}-07$ to 7.13E-04 $\mu \mathrm{g} \mathrm{ml}^{-1}$ ) of dry weight wheat kernels over all Bavaria (Figure $3)$.

By comparing the results of Tri-5 specific PCR assay, DON quantification by HPLC technique, and RT-PCR DNA quantification of $F$. graminearum and F. culmorum for the same wheat samples, we found that the same Tri-5 DNA intensive bright samples that associated with the largest amounts of DON were contained also the highest 


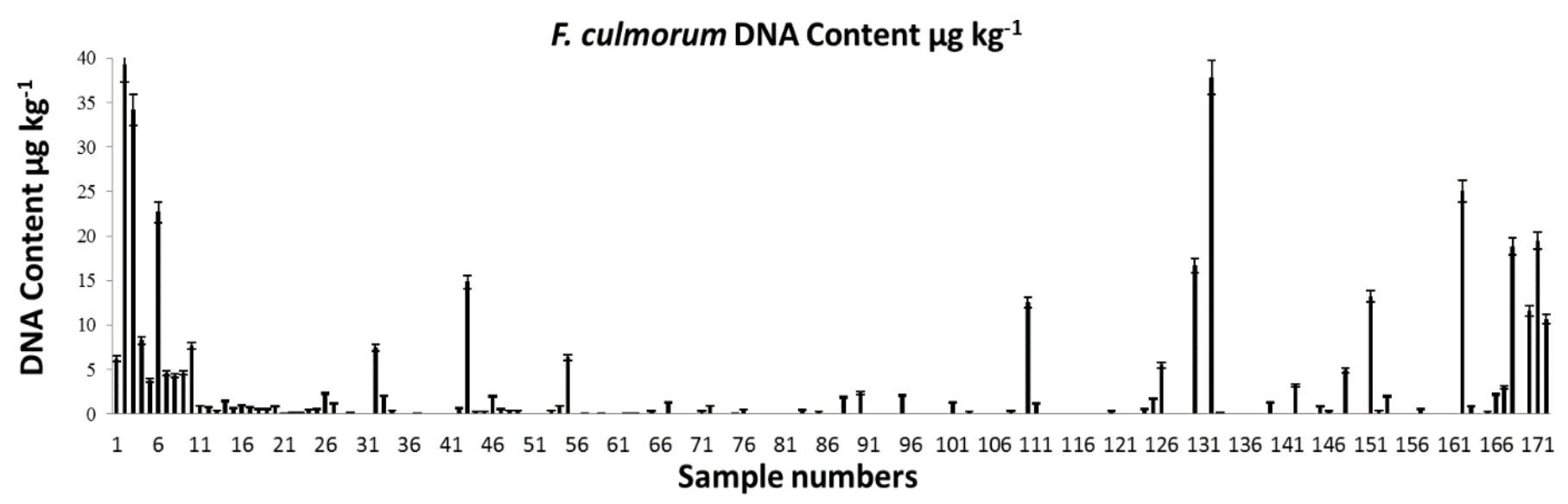

Figure 3: Infestation by F. culmorum in wheat samples harvest by Real-Time SYBR Green 1 dye. Samples were tested in triplicates.

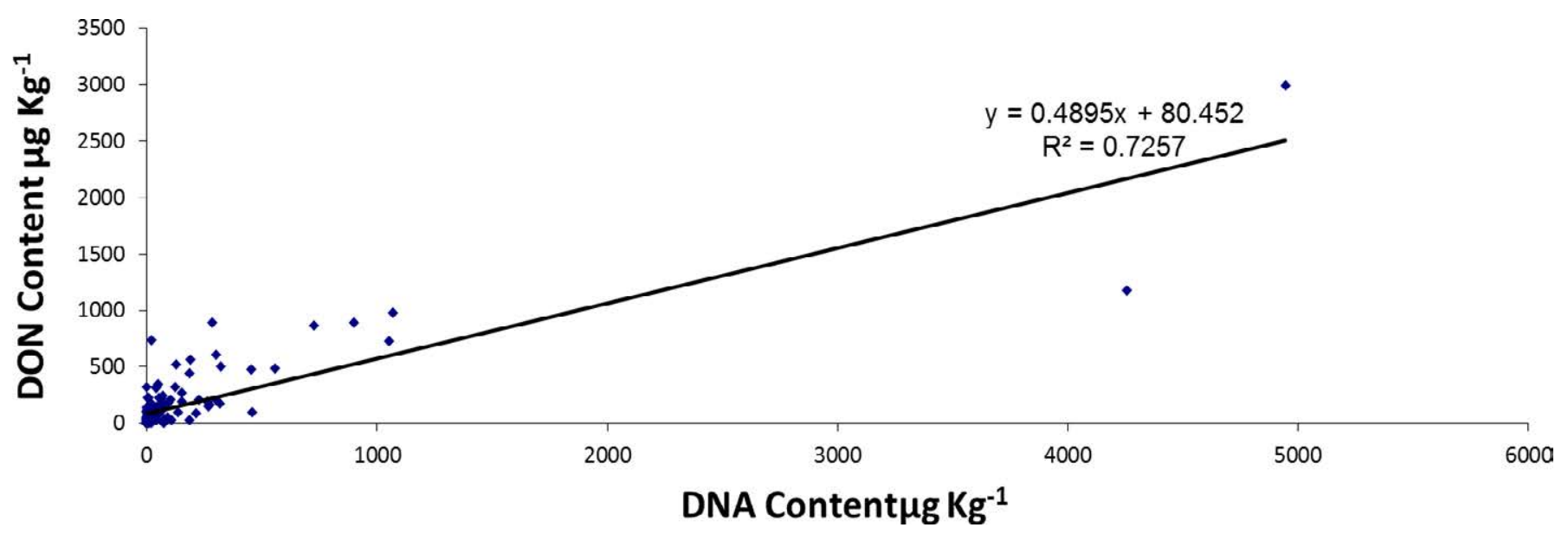

Figure 4: Relationship between DON and F. graminearum DNA content in all samples.

amount of F. graminearum DNA (4945-100.82 $\left.\mu \mathrm{g} \mathrm{kg}^{-1}\right)$ and trace amounts of $F$. culmorum DNA (39.22 to $10.67 \mu \mathrm{g} \mathrm{kg}$ ). Alternatively, faint Tri-5 DNA samples which had a trace amount of DON (10-99 $\mu \mathrm{g}$ $\mathrm{kg}^{-1}$ ) showed trace detectable amounts of both $F$. graminearum DNA ranged from 0.04 to $47.15 \mu \mathrm{g} \mathrm{kg}^{-1}$ and $F$. culmorum DNA ranged from 0.04 to $1.99 \mu \mathrm{g} \mathrm{kg}^{-1}$. In case of absence of Tri-5 gene products which associated with free DON contents (7\% of all samples), there was trace amounts of both F. graminearum and F. culmorum DNA ( 0.72 and 0.78 $\mu \mathrm{g} \mathrm{kg}^{-1}$, respectively). While in case of absence of Tri-5 gene products on agarose gels but with presence of DON in their tissues (the other $7 \%)$, there was trace detectable amounts of both $F$. graminearum DNA (0.66-1.83 $\left.\mu \mathrm{g} \mathrm{kg}^{-1}\right)$ and F. culmorum DNA (0.08-39.22 $\left.\mu \mathrm{g} \mathrm{kg}^{-1}\right)$.

\section{Correlation between $F$. graminearum DNA and DON content}

The plot of F. graminearum DNA content in 172 wheat samples, determined by Real-Time TaqMan probe PCR and the DON content in their tissues determined by HPLC, showed a strong positive linear correlation between both parameters. Correlation coefficient was 0.725 (Figure 4). Moreover, the regression analysis of all data sets indicated a strong and highly significant correlation $(\mathrm{p}<0.05)$ between DON contents in the plant tissues and F. graminearum DNA contents in wheat samples, and the regression equation was $(y=0.4896 x+79.784$; $\mathrm{R}^{2}=0.7252$ ).

\section{Correlation between F. culmorum DNA and DON content}

The plot of DON content against F. culmorum DNA standard curve (Figure 5) showed a slight correlation between DON and F. culmorum DNA, whereas the linear correlation coefficient was $\approx 0.2$ which is very far from +1 . The regression analysis of all data set showed a weak correlation ( $\mathrm{p}<0.01)$ between F. culmorum DNA and DON content, and the regression equation was $\left(y=8.9319 x+117.51 ; \mathrm{R}^{2}=0.0353\right)$.

Moreover, comparison of the results of TaqMan Real-Time PCR for F. graminearum with analysis of DON content for the same samples showed that $73 \%$ of $F$. graminearum presence was associated with DON production. On the contrary, the results of SYBR Green 1 RealTime PCR for F. culmorum with DON content showed that $56 \%$ of $F$. culmorum incidence was associated with DON production. However, in spite of the noticeable infections of wheat grains with F. culmorum $56 \%$, its DNA content was low (0.04- $\left.39.22 \mu \mathrm{g} \mathrm{kg}^{-1}\right)$ compared to that of F. graminearum (0.04 to $4945 \mu \mathrm{g} \mathrm{kg}^{-1}$ Figure 6).

On the other hand, although the $F$. graminearum DNA was not detected in $20 \%$ of samples, but DON was found $\left(10-320 \mu \mathrm{g} \mathrm{kg}^{-1}\right)$ and F. culmorum DNA was detected in some of these samples $\left(2-39 \mu \mathrm{g} \mathrm{kg}^{-1}\right)$ (Figure 7). 


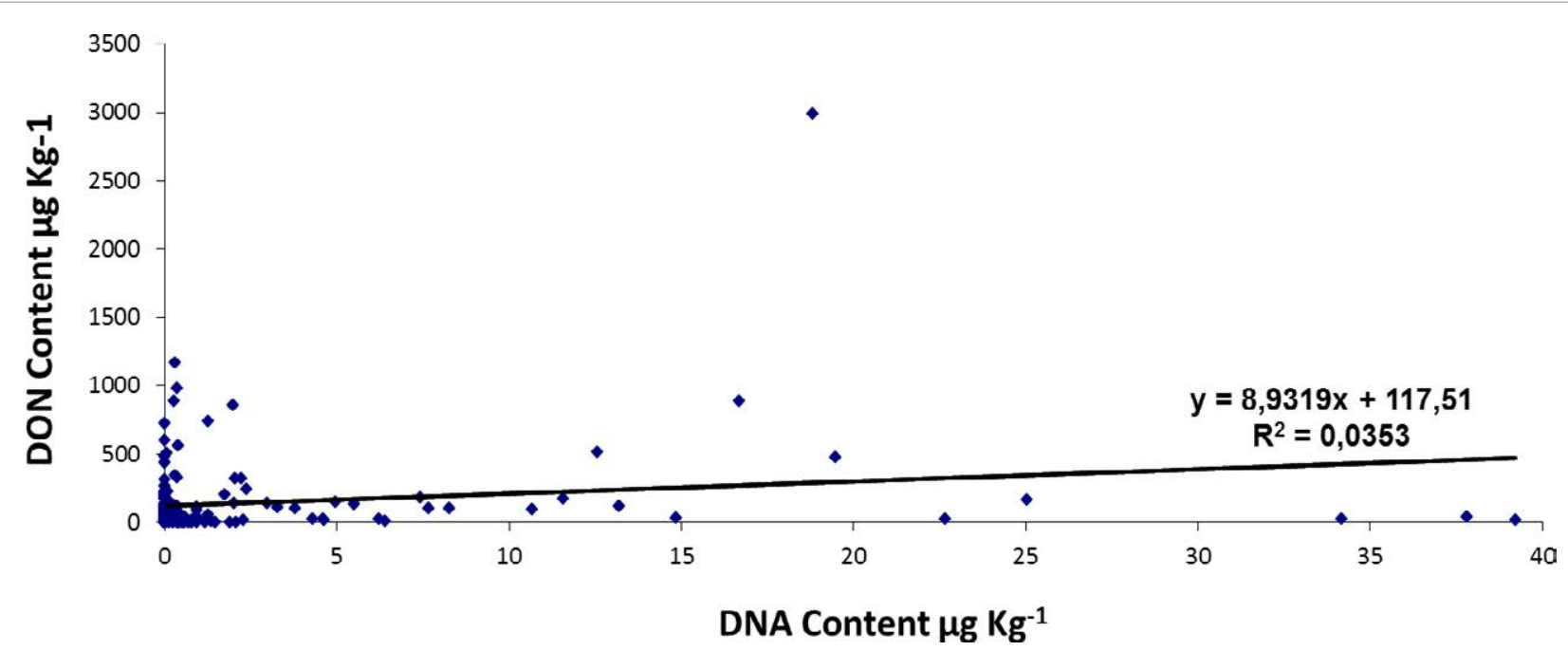

Figure 5: Relationship between DON and F. culmorum DNA content in all samples.
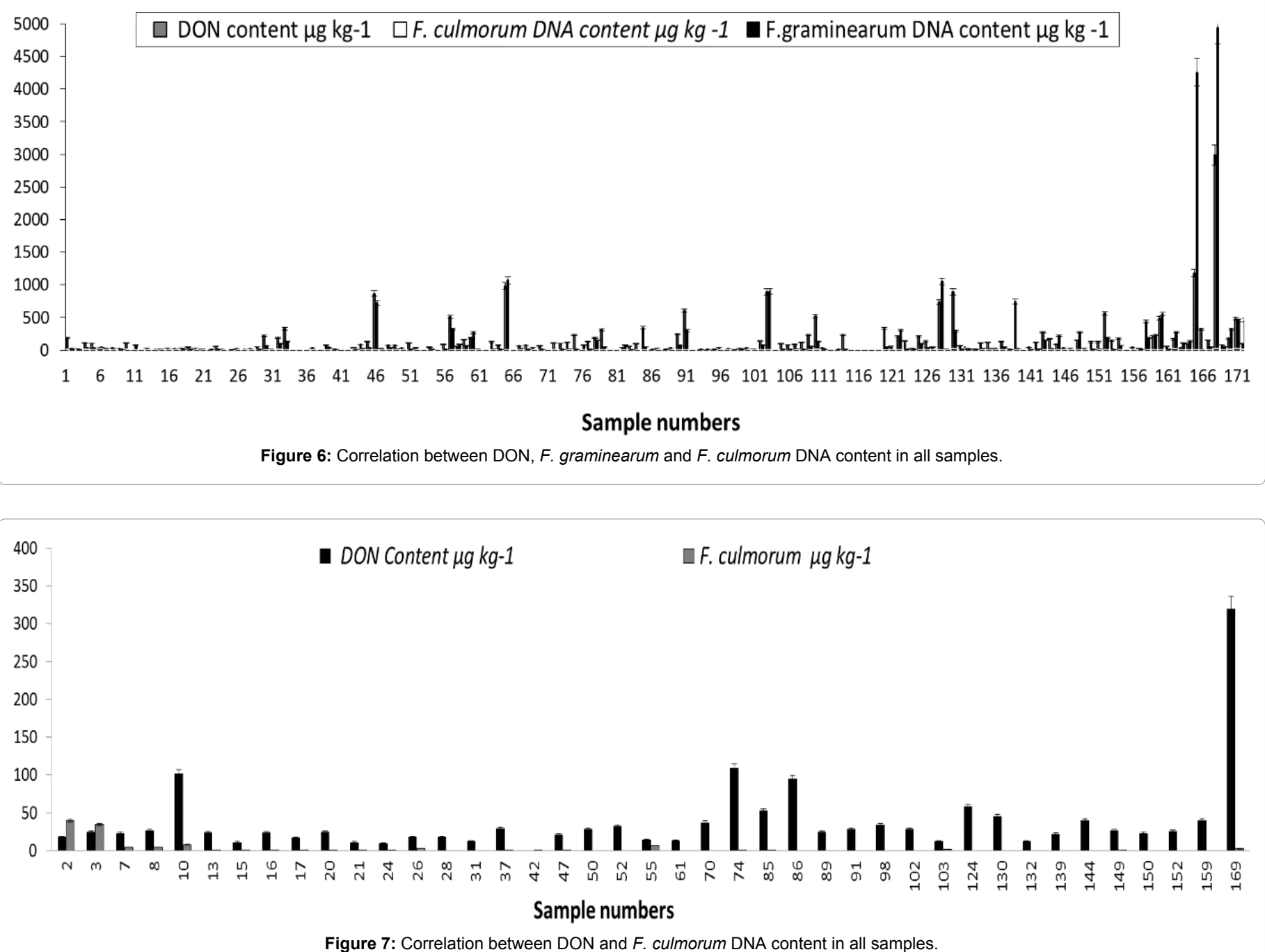


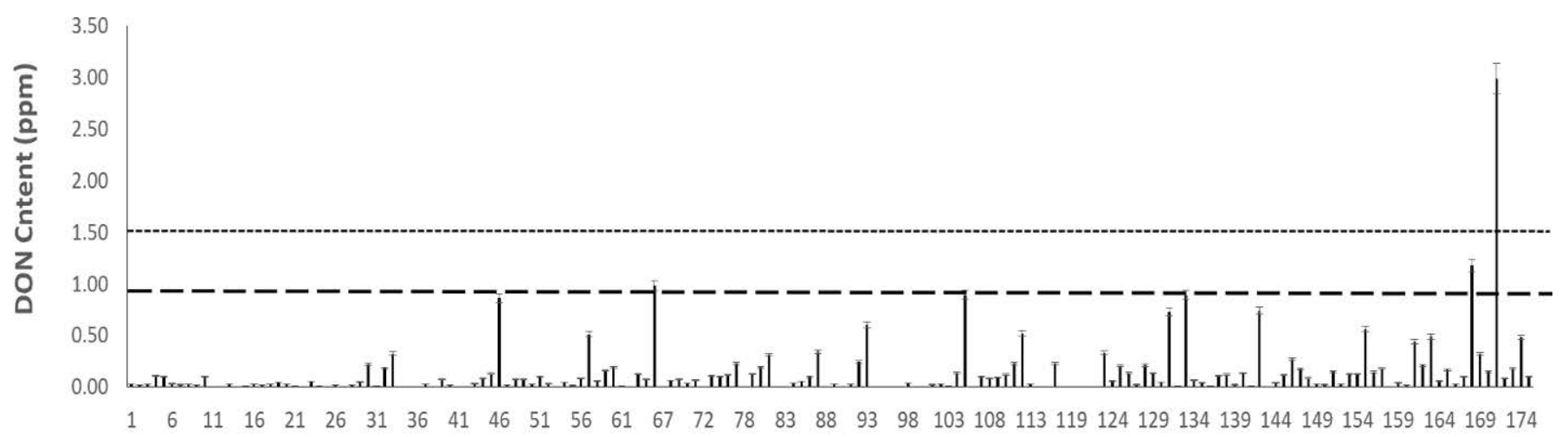

Sample numbers

Figure 8: Relationship between DON content and DON advisory level of EU (dotted line) and FDA (broken line) organization.

\section{Severity of F. graminearum and F. culmorum infection over Bavaria}

The whole picture of DON contents in 172 infected wheat samples was highlighted in Figures 3-8 in comparsion with the DON established threshold by FDA organization and European Union. This figure showed that only two samples of all harvested wheat kernel lay above the FDA DON advisory level of $1 \mathrm{ppm}$, and only one sample is higher than the EU threshold of $1.25 \mathrm{ppm}$.

\section{Discussion}

\section{Identification of trichothecene-producing $F$. spp. by PCR}

Fusarium species are considered as a potential trichotheceneproducing species [15]. The conserved region of Tri-5 gene has been detected in F. culmorum [30,31], F. graminearum [32], F. poae [21], F. sporotrichioides [33], and F. sambucinum [7]. There was a direct relationship between Tri-5 gene expression and the increase in deoxynivalenol production $[34,35]$. Tri-5 primers were designed from highly conserved regions of the Tri-5 gene of Fusarium spp. [17]. A Tri5-specific PCR assay has been developed to detect trichotheceneproducing Fusarium species in contaminated wheat samples [36]. In our study, we used the qualitative Tri-5 specific PCR assay to detect trichothecene-producing Fusarium species in contaminated wheat kernel samples (172 samples) collected from south Germany. 59\% (101 samples) of 172 tested samples were positive in the Tri-5 PCR assay and showed intensive bright DNA bands on agarose gels and were highly infected with one or more of Fusarium species containing Tri-5 gene. Correspondingly, this result was significantly associated with the results of DON content where the same Tri-5 DNA intensive bright samples had simultaneously the highest amount of DON ranged from 101 to $2990 \mu \mathrm{g} \mathrm{kg}^{-1}$. This result was in accordance with some reports on F. avenaceum isolates that were positive in the Tri-5 PCR assay and produced DON in culture [37]. In addition, the results of F. graminearum and F. culmorum DNA quantification by RT-PCR showed that the same Tri-5 DNA intensive bright samples contained also the highest amount of F. graminearum DNA (4945-100.82 $\left.\mu \mathrm{g} \mathrm{kg}^{-1}\right)$ and F. culmorum DNA (39.22-10.67 $\left.\mu \mathrm{g} \mathrm{kg}^{-1}\right)$. Thus, according to our results we could say that there was a significant direct relationship between the density of Tri-5 DNA bands on agarose gels and DON content. The increasing in DON content was also associated with higher concentration of Fusarium species, particularly, of $F$. graminearum DNA and slightly with $F$. culmorum DNA quantified by RT-PCR. In other words, we could say the increased density of Tri-5 DNA bands with the highest amounts of DON were related to the presence of high amounts of $F$. graminearum DNA rather than F. culmorum. For example, the highest amounts of $F$. graminearum DNA in some samples $\left(4945,4255,1069,1050 \mu \mathrm{g} \mathrm{kg}^{-1}\right)$ were associated with the largest amounts of DON $(2990,1174,981,728$ $\mu \mathrm{g} \mathrm{kg}^{-1}$ ) while the concentration of F. culmorum for the same samples were very limited (18.81, 0.30, 0.36, $0.00 \mu \mathrm{g} \mathrm{kg}^{-1}$ respectively Figure 6). On the other hand, faint Tri-5 DNA bands on agarose gels $(27 \%$ of all tested samples) indicated samples containing a low concentration of Tri-5 gene and as a result, the infection with F.spp. was also low. Accordingly, the amount of DON content in these samples was very low and ranged from 10 to $99 \mu \mathrm{g} \mathrm{kg}^{-1}$. These results were in accordance with RT-PCR results, where low amounts of $F$. graminearum DNA (0.04-47.15 $\left.\mu \mathrm{g} \mathrm{kg}^{-1}\right)$ and F. culmorum DNA (0.07-1.99 $\left.\mu \mathrm{g} \mathrm{kg}^{-1}\right)$ were revealed.

Indeed, F.spp-infected wheat kernels that showed negative results in the Tri-5 PCR assay and showing absence of DNA bands on agarose gels should be Tri-5 gene free and should not be infected with $F$. spp. containing Tri-5 gene and ,accordingly, these samples were DON free. In our results, $7 \%$ (12 samples) of all samples were negative in the Tri5 PCR assay and didn't produce DON and they were approximately free of F. graminearum DNA $\left(0.72 \mu \mathrm{g} \mathrm{kg}^{-1}\right)$ and F. culmorum DNA $\left(0.78 \mu \mathrm{g} \mathrm{kg}^{-1}\right)$. It has been demonstrated that within the same species and in the same cultural conditions toxin production by Fusarium strains may vary largely. Some strains produce large amount of trichothecene, whereas others produce small or undetectable amount of trichothecene [38-42]. However, there were other 7\% of samples in which no Tri-5 DNA was detected on agarose gels but an amount of DON ranged from 11 to $226 \mu \mathrm{g} \mathrm{kg}^{-1}$, low detectable amounts of $F$. graminearum DNA ranged from 0.66 to $1.83 \mu \mathrm{g} \mathrm{kg}^{-1}$ and an amount of F. culmorum DNA (0.08-39.22 $\left.\mu \mathrm{g} \mathrm{kg}^{-1}\right)$ were detected. It might be possible that other genes involved in trichothecene biosynthesis have been identified outside the Tri biosynthetic gene cluster including Tri1 [43] and Tri101 [44] which requires more investigation in our samples. However, it is possible that the pathogenic isolates producing DON in very small amounts could produce other phytotxins instead of DON in the pathogenesis [45]. In our study, the same samples that produced Tri-5 DNA intensive bright bands on agarose gels were containing the highest amount of DON revealed by HPLC analysis and had also the largest amounts of $F$. graminearum and $F$. culmorum DNA evaluated by RT-PCR. We conclude from the displayed results that there was a 
Citation: Sanoubar R, Bauer A, Seigner L (2015) Detection, Identification and Quantification of Fusarium graminearum and Fusarium culmorum in Wheat Kernels by PCR Techniques. J Plant Pathol Microb 6: 287. doi:10.4172/2157-7471.1000287

positive relationship between the three techniques used in this study as they provided us with similar results for the same samples.

\section{Quantification of F. graminearum and F. culmorum}

Molecular diagnostic of plant pathogenic fungi can be highly specific, very sensitive, and relatively fast [46]. We used in this study a fast and reliable method for the species-specific identification and absolute quantification of $F$. graminearum and $F$. culmorum. It is a RT-PCR assay using a TaqMan hybridization probe targeting the betatubulin gene for F. graminearum and SYBR Green 1 for F. culmorum. TaqMan method used in this study because of its sensitivity, selectivity, and reduction of fault signals due to primer-dimer formation [46] and allowed a fast species-specific identification and quantitation of plant infections by F. graminearum at very early stages where classical microbiological and toxin analysis methods fail to detect the pathogen [46]. The beta-tubulin gene of all non F. graminearum isolates failed to be amplified in the reaction while targeting DNA from all isolates yielded product in the PCR assay [47]. RT-PCR analysis confirmed that $F$. graminearum was more abundant in the infected grains than $F$. culmorum since the concentration of $F$. graminearum DNA ranged from 0.04 to $4945 \mu \mathrm{g} \mathrm{kg}^{-1}$ while $F$. culmorum DNA content ranged from 0.04 to $39.22 \mu \mathrm{g} \mathrm{kg}^{-1}$. Consequently, $F$. graminearum infections were severe while the severity of F. culmorum infection was not high in wheat kernels. Comparison between the results of TaqMan RealTime PCR analysis for $F$. graminearum and DON content showed that $F$. graminearum is an efficient DON producer where there was high positive significant correlation $\left(\mathrm{R}^{2}=0.7\right)$ between $\mathrm{DON}$ and $F$. graminearum DNA content. Therefore, F. graminearum was considered as the predominant trichothecene associated with FHB and produced the main part of DON in wheat crop. This is in accordance with former investigations [17]. In contrast, the slight weak correlation $\left(\mathrm{R}^{2}=0.03\right)$ between DON and F. culmorum DNA content may reflect that $F$. culmorum was the second important species in the DON producing Fusarium genus. Previous study suggested that F. culmorum along with F. graminearum were consistently the most pathogenic of the Fusarium species infecting cereal ears [12].

Moreover, the PCR analysis showed that in $20 \%$ of total infected samples, DON was found (10-320 $\left.\mu \mathrm{g} \mathrm{kg}^{-1}\right)$ where no $F$. graminearum DNA was detected and that was linked with only slight content of $F$. culmorum DNA (0.10- $39.22 \mu \mathrm{g} \mathrm{kg}^{-1}$ Figure 7). PCR analysis indicated that the presence of other Fusarium species within the field plots may account for the FHB disease and this result was consistent with the observation of ref. [48]. In these cases, DON content is probably attributable to the possibility that FHB infection in the samples is caused by a complex of Fusarium spp. which release DON mycotoxins, and other DON producing Fusarium spp. (like F. pseudograminearum, F. poae and/or F. sporotrichoides) might have been presented, that may require further investigation.

The U.S. Food and Drug Administration (FDA) recommend that DON levels in human foods should not exceed $1 \mathrm{ppm}$. Higher levels of DON are permitted in feed for poultry and ruminant animals. While the European Community supports the setting of European Union (EU) thresholds of trichothecenes as low as reasonably achievable in order to protect public health. For example, DON levels in human foods should not exceed $1.25 \mathrm{ppm}$. In general, the aggressiveness of F. graminearum and F. culmorum was relatively low over all Bavaria since the DON content was generally low (10-2990 $\mathrm{g} \mathrm{kg}^{-1}$ Figure 6). Indeed, the aggressiveness of Fusarium was not so high where only $2 \%$ of all harvested wheat kernel laid above the FDA DON advisory level of $1 \mathrm{ppm}$, and only one sample was higher than the EU threshold of $1.25 \mathrm{ppm}$. Some authors reported that trichothecenes may play an important role in the aggressiveness of fungi towards plant host [49].

\section{References}

1. Dickson JG, Mains EB (1929) Scab of wheat and barley and its control. USDA Farmers Bulletin 1599. pp: 1-18.

2. Dubin HJ, Gilchrist L, Reeves J, McNab A (1997) Fusarium head scab: Global status and prospects. CIMMYT, Mexico, DF, Mexico, p. 130.

3. McMullen MP, Jones R, Gallenberg D (1997b) Scab of wheat and barley: A reemerging disease of devastating impact. Plant Dis 81: 1340-1348.

4. Tuite J, Shaner G, Everson RJ (1990) Wheat scab in soft red winter in Indiana in 1986 and its relation to some quality measurements. Plant Dis 74: 959-962.

5. McMullen MP, Enz J, Lukach J, Stover R (1997a) Environmental conditions associated with Fusarium head blight epidemics of wheat and barley in the Northern Great Plains, North America. Cereal Res Commun 25: 777-778.

6. Liu ZZ, Wang ZY (1990) Improved scab resistance in China: Sources of resistance and problems. In: Saunders DA (ed) Wheat for the Non-traditional Warm Areas. Proc Int. Conf., CIMMYT, Mexico, D.F, pp. 178-188.

7. Hart LP, Ward R, Bafus R, Bedford K (1998) Return of an Old Problem: Fusarium Head Blight of Small Grains. Proceedings of the National Fusarium Head Blight Forum. Michigan State Univ., E. LansingThe American Phytopathological Society.

8. Hanson EW, Ausemus ER, Stakman EC (1950) Varietal resistance of spring wheats to fusarial head blight. Phytopathology 40: 902-914.

9. Mathre DE (1997) Compendium of barley diseases. (2nded) The Am Phytopathological Soc Press, St. Paul, MN.

10. Bechtel DB, Kaleikau LA, Gaines RL, Seitz LM (1985) The effects of Fusarium graminearum infection on wheat kernels. Cereal Chem 62: 191-197.

11. Wood M, Comis D, Harden D, McGraw L, Stelljes KB (1999) Fighting Fusarium Agricultural Research. June issue. USDA-ARS, Beltsville, MD.

12. Parry DW, Jenkinson $P$, McLeod $L$ (1995) Fusarium ear blight (scab) in small grains -a review. Plant Pathol 44: 207-238

13. Muriuki JG (2001) Deoxynivalenol and nivalenol in pathogenesis of Fusarium head blight in wheat. Thesis, University of Minnesota.

14. Stack RW (2003) History of Fusarium head blight with emphasis on North America. In: Leonard KJ, Bushnell WR (ed) Fusarium head blight of wheat and barley. APS Press, St. Paul, MN, pp: 1-34

15. Edwards SG, Pirgozliev SR, Hare MC, Jenkinson P (2001) Quantification of trichothecene-producing Fusarium species in harvested grain by competitive PCR to determine efficacies of fungicides against Fusarium head blight of winter wheat. American Society for Microbiology 67: 1575-1580.

16. Schwarz PB, Casper HH, Barr JM (1995) Survey of the occurrence of deoxynivalenol (vomitoxin) in barley grown in Minnesota North Dakota and South Dakota during 1993. MBAA Tech Q 32: 190- 194.

17. McMullen MP, Schatz B, Stover R, Gregoire T (1997c) Studies of fungicide efficacy, application timing, and application technologies to reduce Fusarum head blight and deoxynivalenol. Cereal Res. Commun. 25: 779-780.

18. Marasas WFO, Nelson PE, Toussoun TA (1984) Toxigenic Fusarium species: identify and mycotoxicology. Pennsylvania State University Press, University Park. Pa.

19. Bottalico A, Perrone G (2002) Toxigenic Fusarium species and mycotoxins associated with head blight in small grain cereals in Europe. European Journal of Plant Pathology 108: 611-624.

20. Boyacioglu D, Hettiarachchy NS, Stack RW (1992) Effect of three systemic fungicides on deoxynivalenol (vomitoxin) production by Fusarium graminearum in wheat. Can J Plant Sci 72: 93-101.

21. van Eeuwijk FA, Mesterhazy A, Kling Cl, Ruckenbauer P, Saur L, et al. (1995) Assessing non-specificity of resistance in wheat to head blight caused by inoculation with European strains of Fusarium culmorum, F. graminearum and F. nivale using a multiplicative model for interaction. Theor Appl Genet 90: 221 228.

22. Bennett JW, Klich M (2003) Mycotoxins. Clin Microbiol Rev 16: 497-516. 
Citation: Sanoubar R, Bauer A, Seigner L (2015) Detection, Identification and Quantification of Fusarium graminearum and Fusarium culmorum in Wheat Kernels by PCR Techniques. J Plant Pathol Microb 6: 287. doi:10.4172/2157-7471.1000287

23. Murphy M, Armstrong D (1995) Fusariosis in patients with neoplastic disease Infect Med 12: 66-67.

24. Berek L, Petri IB, Mesterházy A, Téren J, Molnár J (2001) Effects of mycotoxins on human immune functions in vitro. Toxicol In Vitro 15: 25-30.

25. Lindsay JA (1997) Chronic sequelae of foodborne disease. Emerg Infect Dis 3: $443-452$.

26. Bai G, Kolb FL, Shaner G, Domier LL (1999) Amplified fragment length polymorphism markers linked to a major quantitative trait locus controlling scab resistance in wheat. Phytopathology 89: 343-348.

27. Niessen ML, Vogel RF (1998) Group specific PCR-detection of potential trichothecene-producing Fusarium-species in pure cultures and cereal samples. Syst Appl Microbiol 21: 618-631.

28. Fekete C, Logrieco A, Giczey G, Hornok L (1997) Screening of fungi for the presence of the trichodiene synthase encoding sequence by hybridization to the Tri5 gene cloned from Fusarium poae. Mycopathologia 138: 91-97.

29. Hohn TM, Desjardins AE (1992) Isolation and gene disruption of the Tox5 gene encoding trichodiene synthase in Gibberella pulicaris. Mol Plant Microbe Interact 5: 249-256.

30. Bauer A, Seigner L, Battner P, Tischner H (2004) Monitoring of FHB using PCR for qualitative and quantitative detection of Fusarium spp. Proceedings of the 2nd International Symposium on Fusarium Head Blight 2: 553.

31. Snijders CHA, Krechting CF (1992) Inhibition of deoxynivalenol translocation and fungal colonization in Fusarium head blight resistant wheat. Can J Bot 70 : 1570-1576.

32. Moschini RC, Fortugno C (1996) Predicting wheat head blight incidence using models based in meteorological factors in Pergamino, Argentina. Eur J Plan Pathol 102: 211-218.

33. Hart LP, Pestka JJ, Liu MT (1984) Effect of kernel development and we periods on production of deoxynivalenol in wheat infected with Gibberella zeae. Phytopathology 74: 1415-1418.

34. Fernando WG, Paulitz TC, Seaman WL, Dutilleul P, Miller JD (1997) Head Blight Gradients Caused by Gibberella zeae from Area Sources of Inoculum in Wheat Field Plots. Phytopathology 87: 414-421.

35. Doohan FM, Weston G, Rezanoor HN, Parry DW, Nicholson P (1999) Development and use of a reverse transcription-PCR assay to study expression of Tri5 by Fusarium species in vitro and in planta. Appl Environ Microbiol 65: 3850-3854.

36. Neissen ML, Vogel RF (1997) A molecular approach to the detection of potential trichothecene producing fungi. In: Mesterhazy A (ed) Cereals research communication. Proceeding of the Fifth European Fusarium Seminer, Szeged Hungary-1997.Cereals Reasearch Institute, Szeged, Hungary. pp. 245-249.

37. Abramson D, Clear RM, Smith DM (1993) Trichothecene production by Fusarium spp. isolated from Manitoba grain. Can J Plant Pathol 15: 147-152.

38. Mesterhazy A (1995) Types and components of resistance to Fusarium head blight of wheat. Plant Breeding 114: 377-386.

39. Mesterhzy A (1997) Breeding for resistance to Fusarium head blight of wheat Proceedings of the 5th European Fusarium Seminar. Cereal Res Commun 25: 231-866.

40. Schroeder HW, Christensen JJ (1963) Factors affecting resistance of wheat to scab caused by Gibberella zeae. Phytopathology 53: 831-838.

41. Snijders CHA, Perkowski J (1990) Effects of head blight caused by Fusarium culmorum on toxin content and weight of wheat kernels. Phytopathology 80 566-570.

42. Walker S, Leath S, Hagler W, Murphy J (2001) Variation among isolates of Fusarium graminearum associated with Fusarium head blight in North Carolina. Plant Dis 85: 404-410.

43. McCormick SP, Harris LJ, Alexander NJ, Ouellet T, Saparno A, et al. (2004) Tri1 in Fusarium graminearum encodes a P450 oxygenase. Appl Environ Microbiol 70: 2044-2051.

44. Kimura M, Kaneko I, Komiyama M, Takatsuki A, Koshino H, et al. (1998) Trichothecene 3-O-acetyltransferase protects both the producing organism and transformed yeast from related mycotoxins. Cloning and characterization of Tri101. J Biol Chem 273: 1654-1661.

45. Hestbjerg H, Felding G, Elmholt S (2002) Fusarium culmorum infection of barley seedling: correlation between aggressiveness and deoxynivalenol content. Journal of Phytopathology 4: 308-312.

46. McCartney HA, Foster SJ, Fraaije BA, Ward E (2003) Molecular diagnostics for fungal plant pathogens. Pest Manag Sci 59: 129-142.

47. Reischer GH, Lemmens M, Farnleitner A, Adler A, Mach RL (2004) Quantification of Fusarium graminearum in infected wheat by species specific real-time PCR applying a TaqMan Probe. J Microbiol Methods 59: 141-146.

48. Doohan M F, Parry DW, Jenkinson P, Nicholson P (1998) The use of speciesspecific PCR based assays to analyse Fusarium ear blight of wheat 47: 19-205.

49. Proctor RH, Hohn TM, McCormick SP (1995) Reduced virulence of Gibberella zeae caused by disruption of a trichothecene toxin biosynthetic gene. Mol Plant Microbe Interact 8: 593-601. 